Open Access

\title{
Enterprise innovation in developing countries: an evidence from Ethiopia
}

Megersa Debela Daksa ${ }^{1 *} \mathbb{D}$, Molla Alemayehu Yismaw ${ }^{1}$, Sisay Diriba Lemessa ${ }^{1}$ and Shemelis Kebede Hundie ${ }^{2}$

\author{
* Correspondence: \\ mdebela4@gmail.com \\ 'Department of Economics, \\ Haramaya University, Dire Dawa, \\ Ethiopia \\ Full list of author information is \\ available at the end of the article
}

\begin{abstract}
Enterprise innovation has gained the interest of development policymakers and scholars as the bases for the industrial development. This study comprehensively analyzes the drivers of enterprise innovation in developing countries. The study uses survey data to analyze the determinants of enterprise innovation in Ethiopia using a multivariate probit (MVP) model. For this study, enterprises were grouped into four categories: all-sized, large-sized, medium-sized, and micro- and small-sized enterprises. It appears that engagement in R \& D, on-the-job training, and website ownership significantly determine enterprise innovation. This study, unlike previous studies, comprehensively analyzes drivers of innovation by considering enterprises in different sizes and all at the same time. This helps identify factors most relevant for enterprise innovation at all stage which help policymakers get focused on strategy development. Based on the findings, further emphasis on engagement in $R$ \& D would help enterprises to become innovative for all categories of enterprises. Furthermore, strengthening the available formal training and diversifying type of the training that is related to skills, knowledge, and techniques that help achieve the long-term objective of the enterprises are worth considering. Enterprises also need to subscribe to different sites that help learn more and access information.
\end{abstract}

Keywords: Enterprise, Innovation, Determinants, Multivariate probit, Ethiopia

\section{Background}

Innovation is an engine for economic growth of any economy (Abderrezzak et al. 2016; Abdu and Jibir 2017; African Union Commission (AUC) 2014; Mahendra et al. 2015; NEPAD Planning and Coordinating Agency (NPCA) 2014; van Uden et al. 2016). This is because innovation commitment by a country and/or a firm is often conceptualized as one of the important determinants of enterprise-level productivity gains and country-level economic growth (Abdu and Jibir 2017). Enterprises are playing a crucial role in contributing to economic growth of Ethiopia by supporting science, technology, and innovation activities through research, technology transfer, and diffusion for policy formulation framework (The Federal Democratic Republic of Ethiopia (FDRE) 2010). Innovation is very important for enterprises themselves in increasing competitiveness, creating a value, determining the long-term survival, and raising productivity (Anderson and Potočnik 2014; Beyene et al. 2016; Nam et al. 2017). The ability of a country to sustain rapid economic growth, in the long run, also depends on the effectiveness with which its institutions and policies support the knowledge generation, technological

(c) The Author(s). 2018 Open Access This article is distributed under the terms of the Creative Commons Attribution 4.0 International License (http://creativecommons.org/licenses/by/4.0/), which permits unrestricted use, distribution, and reproduction in any medium, provided you give appropriate credit to the original author(s) and the source, provide a link to the Creative Commons license, and indicate if changes were made. 
transformation, and innovativeness of its enterprises (Ethiopian Science and Agency Technology (ESTA) 2006).

Governments and donors in the developing countries have shown increasing interest in promoting enterprise innovations and entrepreneurship to encourage enterprises. This is due to the potential role enterprise innovation play in the enterprise development for the industrial and economic development. Enterprises create job opportunities and income for the youth and poor in a developing country. The impression is that innovation is important for enterprises to become and remain competitive, to move to higher return activities, and to grow and graduate to a larger enterprise status, hence creating new employment and income opportunities. However, the effectiveness of such interventions by understanding the role of innovation in the growth and development of the economy depends on determining factors influencing innovation (Abdu and Jibir 2017).

Most business enterprises in developing countries like Ethiopia are small- and medium-sized and face various challenges including lack of processed technological information, inadequate training capabilities at technical and vocational education training (TVET) centers, lack of access to financial and other resources and absence of consultancy support (FDRE 2010), poor infrastructural base, and unfavorable government policies which weaken their innovation activities (Abdu and Jibir 2017; Adebowale et al. 2014; Choi and Lim 2017; Dotun 2015; Egbetokun et al. 2016). It is interesting to observe that despite all the difficulties, a large share of firms can still innovate in the African context (Egbetokun et al. 2016; Abdu and Jibir 2017).

The greatest challenge to understanding the role of innovation in the growth and development of the economy has been lacking meaningful data to determine the factors influencing innovation. Moreover, there has been a development of new data sources like the Enterprise Data Survey (EDS) collected by the World Bank which have spurred many empirical studies, in the developed countries, on the determinants of a firm's innovation. Adebowale et al. (2014) argue that some ideas and concepts which have emerged in the innovation systems community have been derived from specific experiences in rich countries and cannot be universal templates. Perhaps the conclusion to be drawn from these studies may be misleading, inconclusive, and difficult to generalize to enterprises in developing countries.

Empirical studies on determinants of innovation by small firms in Africa are relatively scarce (Abdu and Jibir 2017a; Adebowale et al. 2014). Studies conducted on enterprise innovation so far suffer from several limitations. First, they focus only on product and process innovation determinants. The conclusions and policy recommendations derived from these studies cannot be generalized to other innovation types. This is due to the fact that what fosters innovation in process innovations may inhibit/not affect organizational innovations at all. For instance, Stojčić and Hashi (2014) found that cost factors affect product innovations but do not affect process innovations. The study further reveals that firm size fosters new process innovations while it hinders new product innovations. The implication is that some determinants of innovations are specific to the type of innovation the enterprises engaged in. Second, enterprises are almost not homogeneous in size, capability, background, and sector types. Under this circumstance, it is impossible to expect the same factors determining innovation of enterprise (Gebreeyesus 2011). This study reveals that large-sized firms and firms in the manufacturing sector are more likely to engage in innovative activities. Similarly, Hashi and 
Stojcic (2013) noted that under different circumstances, firm size could positively/negatively determine innovation. This proves that the "one-size-fits-all" principle does not work. Third, most of the studies of the enterprise innovation are conducted in the developed countries which may challenge generalization to the developing countries. As developing countries deviate from the developed countries in institutional structures and development infrastructures, it needs due emphasis. This is because the business environment in which enterprises practice may mask the effect of the different factors on the innovation of the enterprise.

There is no comprehensive empirical evidence on determinants of enterprise innovation in developing countries including Ethiopia. The existing few studies in Africa examined the determinants of innovative activity and attributes of innovation (Gebreeyesus 2011). Given the above research gap, this paper contributes to the narrow literature on innovations of enterprises in Ethiopia in the following ways. First, it analyzes not only the determinants of product and/or process innovations but also the determinants of four types of innovations (that is, a new product innovation, a new method of production innovation, a new marketing innovation, and a new organizational structure). Distinguishing enterprises into different sizes helps to identify important factors regarding firms' size. Second, to address the bias that might arise from pooling a heterogeneous group of firms, this study tries to investigate the determinants of innovation by classifying enterprises into all-sized, large-sized, medium-sized, and micro- and small-sized enterprises. Third, contrasting to most of the earlier studies, this study covers not only manufacturing but also retail services and non-retail services.

The rest of the paper is organized as follows. The next section presents a brief literature review. In the third section, the data and method of data analysis is presented. Results and discussions are discussed in the "Results and Discussion" section. Lastly, the conclusions and policy implications are discussed.

\section{Literature review}

The Organization for Economic Cooperation and Development (OECD) defines innovation more broadly as the implementation of a new or significantly improved product (that is, a physical good or service), a process, a new marketing method, or a new organizational method in business practices, workplace organization, or external relations (Organizations for Economic Co-operation (OECD) 2010). Enterprise innovations can arise at different points in the development process, including conception, $\mathrm{R}$ \& $\mathrm{D}$, transfer of the technology to the production organization, production, and marketplace usage (Atkinson 2013).

A wide range of factors affects innovation process, including firm size and age, research and development ( $\&$ \&) efforts, the quality or skill level of managers/employees, employee participation and motivation, managerial practices and inter-departmental cooperation and knowledge exchange, factors related to the firms' network and its interactions with outside organizations, and factors specific to the industry (Egbetokun et al. 2016).

External market target, capacity building, facilitative support to enterprises, and entrepreneur's characteristics determine the innovation ability of enterprise. Enterprises' 
characteristics such as size of the enterprises (Hadhri et al. 2016; De Mel et al. 2009; Stojčić and Hashi 2014; Zemplinerová and Hromádková 2012) and enterprise's maturity (Zakic et al. 2008) determine innovation of the enterprises. By implication, larger and mature enterprises are more innovative than the smaller and less mature enterprises.

Studies show that enterprises' external market target and strategic relation formation determine enterprises' innovation. Foreign market access for the enterprises would help enjoy the large market size for their goods and services and help earn foreign currency which will have a multiplier effect on their activities. Strategic relation behavior of the enterprises would help them with whom to make collaboration in international and national entities. This would help enterprises advance their business. Enterprises that use foreign inputs and that have collaboration with foreign are interrelated (Avermaete et al. 2004). Foreign market orientation of enterprises also determines enterprise innovation (De Mel et al. 2009; Stojčić and Hashi 2014; Zakic et al. 2008; Zemplinerová and Hromádková 2012). This shows that firms that are foreign market-oriented have experience and strategic relation with foreign sectors and are more innovative than their counterparts.

The enterprise's capacity level related to investment in human capital of the enterprises determines the enterprise's innovation. Investment in human capital affects the ability, skills, and knowledge of the workforce of the enterprises. These investments affect innovation of the enterprise. Several studies proliferated this issue. For instance, van Uden et al. (2014) analyzed the impact of human capital innovation in developing countries (Kenya, Tanzania, and Uganda) using data from the Enterprise Surveys of the World Bank and found that human capital spurs innovation. Mahendra et al. (2015) also argued that human capital affects innovation abilities of enterprises in Indonesia. Mahendra et al. (2015) further showed that different combinations of human capital affect innovative output depending on the context in which these combinations are implemented (manufacturing or service sector). Moreover, Audretsch et al. (2016) added that academic-based human capital encourages innovativeness of enterprises while business-based human capital does not play a role.

The firms' extent of investment in the R \& D, skills of the firms' workforce, the firms' investment in know-how (Avermaete et al. 2004; Dotun 2015; Raymond and St-Pierre 2010; Romijn and Albaladejo 2002), and the use of known technology transfer mechanisms (Hadhri et al. 2016) determine the enterprises' propensity to innovate. This shows that the capacity of the enterprises explains their innovative ability.

Empirical evidence shows that the most important factor of innovation is $\mathrm{R}$ \& D activity though findings are mixed. El Elj and El Elj (2012) argued that the value of the $R$ \& D activity is related to the core competencies of the firm and to its efficient innovative processes in Tunisia. However, Aralica et al. (2008) found that continuous engagement in $R$ \& $D$ and $R$ \& D cooperation has turned out to be insignificant in relation to the share of sales of innovative products in Croatia. Some argue in low- and medium-technology industries, creativity, not technological knowledge, is the driver of innovation, because in those industries, 
innovation is based on the general knowledge stock of the firm and the creativity to transform such a stock, instead of scientific research (Goedhuys et al. 2014; Santamaría et al. 2009).

Studies also witness that owner's and entrepreneur's specific characteristics determine enterprise innovation. Owner's characteristics such as the educational background of the owner, prior experience of owner-manager (Avermaete et al. 2004), owner's ability personality traits (De Mel et al. 2009), the age of the entrepreneurs, and the gender of the entrepreneurs (Gebreeyesus 2011) explain firms' innovativeness. Here, the higher the educational level, the younger, and the more the male owners, the more the firms are innovative.

Factors exogenous to the enterprises are also found to be important determinants of the enterprises. These factors are less controllable by the enterprises by themselves. Enterprises that are more active in using available external resources and supports are more likely to be innovative. Few studies showed that facilitative supports such as government support, availability of patent and copyright (Dotun 2015), better institutional quality at the local, access to finance (Mahendra et al. 2015), and the use of external sources of information (Avermaete et al. 2004) determine firms' innovation. These studies' focus contended that external support to the firms determines the firms' innovation.

There are factors which positively and negatively affect enterprise innovations. For instances, foreign ownership of the enterprises (Zemplinerová and Hromádková 2012) and competition (De Mel et al. 2009) negatively affect an enterprise's innovation. Even, there are also factors that do not affect the firms' innovative activities. Characteristics of the entrepreneur (Avermaete et al. 2004), regional networks, and close customer relations (Romijn and Albaladejo 2002) do not determine enterprises' innovation.

Other studies have emphasized on the importance of the innovation for survival in a volatile environment (Johnson et al. 1997). Some studies that have dealt with enterprises' innovation even did not conduct their study by unraveling firms into different respective sizes. Distinguishing enterprises in terms of their size help to identify more relevant factors affecting enterprise innovation. Factor that is more important for a small enterprise may not be important for the large or medium enterprise and vice versa. Identifying factors important in all cases is also worth dealing as it helps policymakers to get focused in devising enterprise innovation and industrial development strategies.

The literature that deals with the characteristics of enterprise innovation activities and connects innovation and other enterprise activities are concerned with the context and content of innovation processes. The focus of the literature, in this case, is whether enterprise innovation activities are related to the existence of $\mathrm{R} \& \mathrm{D}$ activities. The $\mathrm{R} \& \mathrm{D}$ activity is an indispensable part of enterprise innovation activities. A significant amount of innovation and improvements originates from design improvements like "learning by doing" and "learning by using" (Arrow 1962; Mowery and Rosenberg 1989), and such informal efforts are embodied in people and organizations (Teece 1986a, 1986b). These literatures stress an importance of the experience of the enterprises that emanates from the on-the-job training. 
Other literatures point out the link between innovation and enterprise-level determinants of innovation characteristics such as firm size (Aralica et al. 2008; Mahendra et al. 2015). Following the work by Schumpeter (1942), there has been a wide-ranging debate on the differences and complementary qualities of small and large firms in the face of innovation and technological change. As per Schumpeter (1942), large firms have advantages in comparison with small ones when taking part in innovation activities and, what is more, these advantages increase according to firm size. In addition, size emerges as a primary internal force driving technological innovation (Alsharkas 2014) and its relevance is motivated by several intertwined arguments. This hypothesis has been reviewed in various empirical studies without any definite conclusion being reached that there is a positive relationship between the propensity to innovate and firm size for Sri Lanka (De Mel et al. 2009), for Lebanese (Hadhri et al. 2016), for Nigeria (Moohammad et al. 2014), and for Ethiopia (Gebreeyesus 2011). On the other hand, some scholars (Martínez-ros and Labeaga 2002); Plehn-Dujowich 2009) argue that firm's size and innovation abilities are inversely related because they are more dynamic in the decision to innovate. Some studies found innovation to be negatively related to firm size for Croatia (Aralica et al. 2008). Some of the authors found an inverted- $U$ relationship between firm size and $R$ \& D intensity, i.e., the ratio of $R$ \& D expenditure or personnel to size, or between firm size and the ratio of patents to size (Koouba, Karim et al. 2010).Others found a positive relationship up to a certain threshold and no significant effect for larger firms.

The inconclusive results regarding the effect of firm size on innovative capacity of the firms justify the inclusion of many control variables to get robust results (Hadhri et al. 2016). For instance, a systematic review by Becheikh et al. (2006) shows there are about 40 determinants concerning the characteristics of innovating firms. According to Becheikh et al. (2006), these driving forces of innovation are categorized into internal determinants of innovation and contextual determinants of innovation. Internal determinants of innovation include firms' general characteristics (age of the firm, ownership structure, past performance), firms' global strategies (export/internalization, external/internal growth), firms' structure (formalization, centralization, and interaction), management team (leadership variables and manager-related variables), and functional assets and strategies ( $R \& D$, human resources, finance, etc.). Contextual determinants of innovation are firms' industry-related variables (sector, demand growth, industry concentration), firm's regional variables (geographic location and proximity advantage), networking, knowledge/technology acquisition, government and public policies, and surrounding culture.

The impact of these internal and contextual determinants of firm's innovation activities have been studied in developing countries showing varying, inconclusive, and contradictory results (Becheikh et al. 2006; Hadhri et al. 2016).

\section{Result and discussion}

\section{Descriptive statistics results}

Description of variables used in the study and their descriptive statistics are presented in Table 1. The descriptive result shows that, during the last 3 years, $40 \%$ of enterprises introduced a new product innovation; 34\% of them introduced a new method of 
Table 1 Summary of descriptive statistics results

\begin{tabular}{|c|c|c|c|c|c|c|}
\hline Variable & Variable description and measurement & Obs & Mean & $\begin{array}{l}\text { Std. } \\
\text { dev. }\end{array}$ & Min & $\operatorname{Max}$ \\
\hline $\begin{array}{l}\text { h1 (new product } \\
\text { innovation) }\end{array}$ & $\begin{array}{l}\text { Dummy variable that takes the value } \\
\text { one (1) if the enterprise has introduced } \\
\text { new product, } 0 \text { otherwise. }\end{array}$ & 1487 & 0.40 & 0.49 & 0 & 1 \\
\hline $\begin{array}{l}\text { h3 (new method of } \\
\text { production innovation) }\end{array}$ & $\begin{array}{l}\text { Dummy variable that takes the value one } \\
\text { (1) if the enterprise has introduced new } \\
\text { method of production, } 0 \text { otherwise. }\end{array}$ & 1488 & 0.34 & 0.47 & 0 & 1 \\
\hline $\begin{array}{l}\text { h5 (new organizational } \\
\text { structure innovation) }\end{array}$ & $\begin{array}{l}\text { Dummy variable that takes the value one } \\
\text { (1) if the enterprise has introduced new } \\
\text { organizational structure, } 0 \text { otherwise. }\end{array}$ & 1485 & 0.30 & 0.46 & 0 & 1 \\
\hline $\begin{array}{l}\text { h6 (new marketing } \\
\text { methods innovation) }\end{array}$ & $\begin{array}{l}\text { Dummy variable that takes the value one } \\
\text { (1) if the enterprise has introduced new } \\
\text { marketing methods, } 0 \text { otherwise. }\end{array}$ & 1488 & 0.34 & 0.47 & 0 & 1 \\
\hline a6b (size) & $\begin{array}{l}\text { It is a categorical variable that takes the } \\
\text { values } 0,1,2 \text {, and } 3 \text { if the enterprise is micro, } \\
\text { small, medium, and large respectively. It } \\
\text { measures the size of the enterprise. }\end{array}$ & 1492 & 1.71 & 0.82 & 0 & 3 \\
\hline $\begin{array}{l}\text { a3b (location of the } \\
\text { enterprise) }\end{array}$ & $\begin{array}{l}\text { It is a dummy variable that takes the value } \\
\text { one (1) if the enterprise is in the capital city, } \\
0 \text { otherwise. }\end{array}$ & 1492 & 0.62 & 0.49 & 0 & 1 \\
\hline Fage (age) & $\begin{array}{l}\text { It is the age of the enterprise measured in } \\
\text { years. }\end{array}$ & 1476 & 13.67 & 12.02 & 0 & 89 \\
\hline $\begin{array}{l}\text { Fagesqr (age square of the } \\
\text { enterprise) }\end{array}$ & It is the age square of the enterprise & 1476 & 331.21 & 753.31 & 0 & 7921 \\
\hline $\begin{array}{l}\text { b7 (experience of top } \\
\text { manager) }\end{array}$ & $\begin{array}{l}\text { It is the years of experience of the top } \\
\text { manager measured in years. }\end{array}$ & 1466 & 14.02 & 9.95 & 0 & 60 \\
\hline $\begin{array}{l}\text { b7a (gender of top } \\
\text { manager) }\end{array}$ & $\begin{array}{l}\text { It is a dummy variable that takes the } \\
\text { value one (1) if female, otherwise } 0 .\end{array}$ & 1491 & 0.10 & 0.30 & 0 & 1 \\
\hline c22b (website ownership) & $\begin{array}{l}\text { It a dummy variable that takes value one } \\
\text { (1)1 if enterprise owns website, } 0 \text { otherwise. }\end{array}$ & 1485 & 0.38 & 0.49 & 0 & 1 \\
\hline $\begin{array}{l}\mathrm{d} 3 \mathrm{c} \text { (share of direct } \\
\text { export) }\end{array}$ & $\begin{array}{l}\text { It is a continuous variable that measures } \\
\text { enterprises' share of export measured in } \\
\text { percentage. }\end{array}$ & 1484 & 4.95 & 19.10 & 0 & 100 \\
\hline 19b (education) & $\begin{array}{l}\text { It is a continuous variable that measures the } \\
\text { percentage of full-time permanent workers } \\
\text { who completed secondary school. }\end{array}$ & 1457 & 68.03 & 29.73 & 0 & 100 \\
\hline I10 (formal training) & $\begin{array}{l}\text { It is a dummy variable that takes the value } \\
\text { one }(1) \text { if there is availability of formal training } \\
\text { programs for permanent full-time employees, } \\
\text { otherwise } 0 \text {. }\end{array}$ & 1486 & 0.22 & 0.41 & 0 & 1 \\
\hline 11 (permanent workers) & $\begin{array}{l}\text { It is a continuous variable that measures the } \\
\text { number of permanent full-time workers in the } \\
\text { enterprise. }\end{array}$ & 1467 & 96.31 & 361.73 & 1 & 7600 \\
\hline h7 (formal R \& D) & $\begin{array}{l}\text { It is a dummy variable that takes the value } \\
\text { one (1) if the enterprise has spent on formal } \\
R \& D \text { activities that last } 3 \text { years, otherwise } 0 .\end{array}$ & 1488 & 0.14 & 0.34 & 0 & 1 \\
\hline
\end{tabular}

Source: Own computation, 2017

production innovation; 30\% of them introduced a new organizational structure innovation; and 34\% of them introduced new marketing methods.

From the descriptive result, it is showed that $1.74 \%$ enterprises were micro-enterprises, $46.38 \%$ of them were small enterprises, $30.63 \%$ of them were medium enterprises, and $21.25 \%$ of them were large enterprises. The result also showed that majority of the enterprises (62\%) is in the capital city of the country. 
About 10\% enterprises had a female top manager. There were 38\% enterprises that had and own a website. During the last 3 years, about $22 \%$ of the enterprises conducted formal training programs for their permanent full-time employees, while only $14 \%$ of them spend on formal R \& D activities.

The average age of the enterprises is 14 years. The mean top manager's experience is 14 years. On average enterprises, the share of the direct export is about $5 \%$. Out of the full-time permanent workers of the enterprises, $68 \%$ of them have above secondary school education level. Table 1 presents the minimum, maximum, and standard deviations.

\section{Econometric analysis}

Tables 2 and 3 present the estimated effects of the multivariate probit model on factors affecting enterprises' innovation (new product innovation, a new method of production

Table 2 Multivariate probit results of parameter estimates

\begin{tabular}{|c|c|c|c|c|c|c|c|c|}
\hline \multirow[t]{2}{*}{ Variable } & \multicolumn{4}{|l|}{ All-sized } & \multicolumn{4}{|c|}{ Large-sized } \\
\hline & $\mathrm{H} 1$ & $\mathrm{H} 3$ & $\mathrm{H} 5$ & $\mathrm{H} 6$ & $\mathrm{H} 1$ & $\mathrm{H3}$ & $\mathrm{H} 5$ & $\mathrm{H} 6$ \\
\hline \multirow[t]{2}{*}{ a6b } & 0.161 & 0.216 & 0.215 & 0.062 & & & & \\
\hline & $(2.97)^{* *}$ & $(4.04)^{* *}$ & $(3.81)^{* *}$ & -1.08 & & & & \\
\hline \multirow[t]{2}{*}{ a3b } & 0.155 & 0.103 & -0.02 & 0.025 & 0.153 & 0.125 & 0.232 & 0.194 \\
\hline & $(2.02)^{*}$ & -1.33 & -0.24 & -0.3 & -0.85 & -0.67 & -1.21 & -1 \\
\hline \multirow[t]{2}{*}{ Fage } & -0.004 & -0.004 & -0.002 & 0.004 & -0.004 & -0.012 & -0.002 & 0.007 \\
\hline & -0.44 & -0.43 & -0.21 & -0.43 & -0.24 & -0.76 & -0.15 & -0.4 \\
\hline \multirow[t]{2}{*}{ Fagesqr } & 0.0 & 0.0 & 0.0 & 0.0 & 0.0 & 0.0 & 0.0 & 0.0 \\
\hline & -0.63 & -0.78 & -0.08 & -0.03 & -0.34 & -1.04 & -0.31 & -0.13 \\
\hline \multirow[t]{2}{*}{ b7 } & 0.007 & -0.001 & -0.003 & -0.009 & 0.003 & -0.004 & -0.009 & 0.002 \\
\hline & -1.8 & -0.28 & -0.72 & $(2.22)^{*}$ & -0.34 & -0.5 & -1.07 & -0.25 \\
\hline \multirow[t]{2}{*}{ b7a } & 0.086 & 0.109 & 0.014 & -0.09 & -0.438 & -0.126 & -0.327 & -0.452 \\
\hline & -0.74 & -0.96 & -0.11 & -0.69 & -1.35 & -0.4 & -0.96 & -1.3 \\
\hline \multirow[t]{2}{*}{$c 22 b$} & 0.283 & 0.455 & 0.498 & 0.561 & 0.333 & 0.115 & 0.248 & 0.175 \\
\hline & $(3.44)^{* *}$ & $(5.41)^{* *}$ & $(5.71)^{* *}$ & $(6.43)^{* *}$ & -1.94 & -0.66 & -1.35 & -0.91 \\
\hline \multirow[t]{2}{*}{$d 3 c$} & -0.001 & 0 & -0.001 & 0 & 0 & 0.001 & -0.004 & -0.003 \\
\hline & -0.72 & -0.08 & -0.28 & -0.1 & -0.07 & -0.29 & -1.09 & -0.78 \\
\hline \multirow[t]{2}{*}{ 19b } & 0.004 & 0.003 & 0.005 & 0.003 & 0.001 & 0.001 & 0.004 & 0.003 \\
\hline & $(3.41)^{* *}$ & $(2.36)^{*}$ & $(3.22)^{* *}$ & $(2.46)^{*}$ & -0.24 & -0.41 & -1.2 & -0.85 \\
\hline \multirow[t]{2}{*}{110} & 0.475 & 0.426 & 0.645 & 0.499 & 0.388 & 0.453 & 0.537 & 0.674 \\
\hline & $(5.20)^{* *}$ & $(4.57)^{* *}$ & $(6.97)^{* *}$ & $(5.24)^{* *}$ & $(2.35)^{*}$ & $(2.67)^{* * *}$ & $(3.17)^{* *}$ & $(3.85)^{* *}$ \\
\hline \multirow[t]{2}{*}{11} & 0.0 & 0.0 & 0.0 & 0.0 & 0.0 & 0.0 & 0.0 & 0.0 \\
\hline & -0.49 & -1.53 & -1.26 & -1.27 & -0.85 & -1.38 & -0.82 & -1.05 \\
\hline \multirow[t]{2}{*}{ h7 } & 0.574 & 0.5 & 0.731 & 1.164 & 0.336 & 0.482 & 0.953 & 1.458 \\
\hline & $(5.13)^{* *}$ & $(4.51)^{* *}$ & $(6.59)^{* *}$ & $(9.59)^{* *}$ & -1.8 & $(2.46)^{*}$ & $(5.00)^{* *}$ & $(6.48)^{* *}$ \\
\hline \multirow[t]{2}{*}{ _cons } & -1.408 & -1.468 & -1.615 & -1.21 & -0.484 & -0.327 & -1.004 & -1.212 \\
\hline & $(7.22)^{* *}$ & $(7.37)^{* *}$ & $(7.45)^{* *}$ & $(5.54)^{* *}$ & -1.09 & -0.75 & $(2.16)^{*}$ & $(2.40)^{*}$ \\
\hline N & 1376 & & & & 280 & & & \\
\hline
\end{tabular}


Table 3 Multivariate probit innovation determinants result (continued)

\begin{tabular}{|c|c|c|c|c|c|c|c|c|}
\hline \multirow[t]{2}{*}{ Variable } & \multicolumn{4}{|c|}{ Medium-sized } & \multicolumn{4}{|c|}{ Micro- and small-sized } \\
\hline & $\mathrm{H} 1$ & $\mathrm{H} 3$ & $\mathrm{H} 5$ & $\mathrm{H} 6$ & $\mathrm{H} 1$ & $\mathrm{H} 3$ & $\mathrm{H} 5$ & $\mathrm{H} 6$ \\
\hline \multirow[t]{2}{*}{$a 6 b$} & - & - & - & - & - & - & - & - \\
\hline & - & - & - & - & - & - & - & - \\
\hline \multirow[t]{2}{*}{$a 3 b$} & 0.194 & 0.099 & 0.055 & 0.139 & 0.147 & 0.149 & -0.147 & -0.062 \\
\hline & -1.35 & -0.7 & -0.36 & -0.92 & -1.3 & -1.28 & -1.11 & -0.49 \\
\hline \multirow[t]{2}{*}{ Fage } & -0.014 & 0.015 & 0.013 & 0.01 & -0.001 & -0.029 & -0.029 & -0.007 \\
\hline & -0.69 & -0.75 & -0.75 & -0.48 & -0.05 & -1.46 & -1.64 & -0.38 \\
\hline \multirow[t]{2}{*}{ fagesqr } & 0.0 & 0.0 & 0.0 & 0.0 & 0.0 & 0.0 & 0.001 & 0.0 \\
\hline & -0.31 & -0.86 & -1.55 & -0.51 & -0.64 & -1.08 & -1.66 & -0.46 \\
\hline \multirow[t]{2}{*}{ b7 } & 0.006 & -0.001 & 0.009 & -0.002 & 0.01 & 0.009 & -0.004 & -0.017 \\
\hline & -0.83 & -0.15 & -1.15 & -0.28 & -1.64 & -1.23 & -0.56 & $(2.22)^{*}$ \\
\hline \multirow[t]{2}{*}{ b7a } & 0.156 & 0.102 & 0.01 & 0.12 & 0.156 & 0.325 & 0.12 & -0.119 \\
\hline & -0.81 & -0.47 & -0.05 & -0.52 & -0.97 & $(2.10)^{*}$ & -0.63 & -0.62 \\
\hline \multirow[t]{2}{*}{$c 22 b$} & 0.264 & 0.113 & 0.364 & 0.463 & 0.313 & 1.027 & 0.792 & 0.828 \\
\hline & -1.93 & -0.81 & $(2.49)^{*}$ & $(3.20)^{* *}$ & $(2.36)^{*}$ & $(7.55)^{* *}$ & $(5.57)^{* *}$ & $(6.02)^{* *}$ \\
\hline \multirow[t]{2}{*}{$d 3 c$} & 0.001 & -0.002 & -0.005 & -0.003 & -0.005 & 0 & 0.004 & 0.003 \\
\hline & -0.19 & -0.68 & -1.45 & -0.95 & -1.51 & -0.12 & -1.26 & -0.85 \\
\hline \multirow[t]{2}{*}{$19 b$} & 0.002 & 0.003 & 0.004 & 0 & 0.007 & 0.003 & 0.005 & 0.005 \\
\hline & -0.88 & -1.24 & -1.71 & -0.07 & $(3.71)^{* *}$ & -1.66 & $(2.36)^{*}$ & $(2.24)^{*}$ \\
\hline \multirow[t]{2}{*}{110} & 0.329 & 0.276 & 0.452 & 0.251 & 0.675 & 0.494 & 0.813 & 0.564 \\
\hline & $(2.20)^{*}$ & -1.82 & $(2.90)^{* *}$ & -1.64 & $(3.80)^{* *}$ & $(2.61)^{* *}$ & $(4.41)^{* *}$ & $(3.10)^{* *}$ \\
\hline \multirow[t]{2}{*}{11} & 0.002 & 0.002 & 0.008 & 0.003 & -0.008 & 0.015 & 0.007 & 0.003 \\
\hline & -0.79 & -0.61 & $(3.00)^{* *}$ & -1.16 & -0.79 & -1.39 & -0.61 & -0.27 \\
\hline \multirow[t]{2}{*}{ h7 } & 0.709 & 0.626 & 0.781 & 1.164 & 0.866 & 0.76 & 0.654 & 1.242 \\
\hline & $(3.91)^{* *}$ & $(3.50)^{* *}$ & $(4.21)^{* *}$ & $(6.28)^{* *}$ & $(3.68)^{* *}$ & $(3.15)^{* *}$ & $(2.87)^{* *}$ & $(5.18)^{* *}$ \\
\hline \multirow[t]{2}{*}{ _cons } & -0.934 & -1.068 & -1.655 & -1.214 & -1.49 & -1.562 & -1.266 & -1.028 \\
\hline & $(2.71)^{* *}$ & $(2.92)^{* *}$ & $(4.47)^{* *}$ & $(3.16)^{* *}$ & $(4.99)^{* *}$ & $(5.14)^{* *}$ & $(3.71)^{* *}$ & $(2.93)^{* *}$ \\
\hline N & 425 & & & & 671 & & & \\
\hline
\end{tabular}

${ }^{*} p<0.05 ;{ }^{* *} p<0.01$

Source: Own computation 2017

innovation, a new marketing method innovation, and a new organizational structure innovation) based on two scenarios (regardless of enterprises' size and based on their size). Analyzing determinants of enterprises' innovation endeavors by segregating enterprises into different size helps to identify important size-dependent factors that affect enterprises' innovation. It helps to uncover factors which determine enterprises' innovation abilities regardless of the enterprises' size.

In what follows, we present and discuss the determinants of enterprise innovation. Then, we conclude and recommend.

\section{Innovation in all-sized enterprises}

The multivariate probit regression result shows that website ownership, the percentage of full-time permanent workers who completed secondary school, the availability of formal training programs for permanent full-time employees, and engagement of the 
enterprises in R \& D activities significantly affect the four enterprises' innovations irrespective of the enterprises' size (see Table 4 for a summary of the main results). The implication of this finding is that enterprises, regardless of their size, that have access to information, have more educated permanent full-time workers, have a regular on-the-job training program for the workers, and conduct research and development are more innovative than their counterparts.

Table 4 Main results of the finding

\begin{tabular}{|c|c|c|c|c|c|}
\hline & Variables & $\begin{array}{l}\text { Website } \\
\text { ownership: } \\
1 \text { yes, } 0 \\
\text { otherwise }\end{array}$ & $\begin{array}{l}\text { Percentage of } \\
\text { full-time permanent } \\
\text { workers who } \\
\text { completed } \\
\text { secondary school }\end{array}$ & $\begin{array}{l}\text { Formal training } \\
\text { programs for its } \\
\text { permanent, } \\
\text { full-time employees: } \\
1 \text { yes, } 0 \text { otherwise }\end{array}$ & $\begin{array}{l}\text { Spending on formal } \\
\text { research and } \\
\text { development } \\
\text { activities last } 3 \text { years: } \\
1 \text { yes, } 0 \text { otherwise }\end{array}$ \\
\hline \multirow[t]{4}{*}{ All-sized } & $\begin{array}{l}\text { New product } \\
\text { innovation }(\mathrm{H} 1)\end{array}$ & + & + & + & + \\
\hline & $\begin{array}{l}\text { New method of } \\
\text { production } \\
\text { innovation }(\mathrm{H} 3)\end{array}$ & + & + & + & + \\
\hline & $\begin{array}{l}\text { New organizational } \\
\text { structure innovation } \\
(\mathrm{H} 5)\end{array}$ & + & + & + & + \\
\hline & $\begin{array}{l}\text { New marketing } \\
\text { method innovation } \\
(\mathrm{H} 6)\end{array}$ & + & + & + & + \\
\hline \multirow[t]{4}{*}{ Large-size } & $\begin{array}{l}\text { New product } \\
\text { innovation }(\mathrm{H} 1)\end{array}$ & & & + & + \\
\hline & $\begin{array}{l}\text { New method of } \\
\text { production } \\
\text { innovation }(\mathrm{H} 3)\end{array}$ & & & + & + \\
\hline & $\begin{array}{l}\text { New organizational } \\
\text { structure innovation } \\
(\mathrm{H} 5)\end{array}$ & & & + & + \\
\hline & $\begin{array}{l}\text { New marketing } \\
\text { method innovation } \\
(\mathrm{H} 6)\end{array}$ & & & + & + \\
\hline \multirow[t]{4}{*}{$\begin{array}{l}\text { Medium- } \\
\text { sized }\end{array}$} & $\begin{array}{l}\text { New product } \\
\text { innovation }(\mathrm{H} 1)\end{array}$ & & & + & + \\
\hline & $\begin{array}{l}\text { New method of } \\
\text { production } \\
\text { innovation }(\mathrm{H} 3)\end{array}$ & & & + & + \\
\hline & $\begin{array}{l}\text { New organizational } \\
\text { structure innovation } \\
(\mathrm{H} 5)\end{array}$ & + & & + & + \\
\hline & $\begin{array}{l}\text { New marketing } \\
\text { method innovation } \\
(\mathrm{H} 6)\end{array}$ & + & & + & + \\
\hline \multirow[t]{4}{*}{$\begin{array}{l}\text { Micro- and } \\
\text { small-sized }\end{array}$} & $\begin{array}{l}\text { New product } \\
\text { innovation }(\mathrm{H} 1)\end{array}$ & + & + & + & + \\
\hline & $\begin{array}{l}\text { New method of } \\
\text { production } \\
\text { innovation }(\mathrm{H} 3)\end{array}$ & + & + & + & + \\
\hline & $\begin{array}{l}\text { New organizational } \\
\text { structure innovation } \\
\text { (H5) }\end{array}$ & + & + & + & + \\
\hline & $\begin{array}{l}\text { New marketing } \\
\text { method innovation } \\
(\mathrm{H} 6)\end{array}$ & + & + & + & + \\
\hline
\end{tabular}

+ indicates variables are significant in determining the innovation 
Enterprises which have their own website are more likely innovative than those do not have a website. Social networking sites like website provide information about individuals and their networks which enables enterprises to create online social communities shared by external stakeholders. A website helps enterprises interact with external factors such as customers and public institutions. This helps enterprise get, transfer, and assimilate external knowledge within the enterprise and then generate innovation. Moreover, according to the triple helix theory, the success of innovation endeavors depends on what integration and cooperative interaction develop between the academia, the private sector, and the government which is shaped by the social networking sites. Our finding is in line with that of Scuotto et al. (2016), Martins (2016), Guo et al. (2016), and Del Giudice et al. (2016). Having a website may help enterprises to use all possible available resources in the world via the Internet. These resources may be related to new technologies (production), knowledge, and techniques helpful in upgrading the method of production, management of resources, marketing of the products, and so on. They may also use the Internet to identify areas of more demanded products they focus on. Enterprises may conduct an assessment of their product, a method of production, and management through an online survey using their website. Thus, website ownership may determine enterprise innovation through the provision of important information, resources, and online survey services.

Tables 2 and 3 show that different aspects of human capital (general level of schooling and formal on-the-job training) ignite enterprises', regardless of size, innovation of all types. Enterprises investing in formal training programs for its permanent and full-time employees are more likely innovative than otherwise because it is a worker with knowledge and skill who can generate new knowledge and ability to absorb new knowledge created by other enterprise's employees. Another component of human capital which is a driving force for innovation in this study is a level of schooling attained by the permanent employees. The result shows that the percentage of employees of the enterprises who completed secondary school increases the enterprises' chance of innovativeness. This is because a high number of workers who completed secondary school generates a high level of knowledge and techniques and induces enterprises to develop innovative new practices. The employee of the enterprises with a high school education level may learn from each other, and this may have spillover effects. The spillover effects of this education even may spread to the enterprise's employee with a lower level of education. In this way, even employees with a lower level of education may gain experience and this would stimulate the whole activities of the enterprise. The enterprise's employee with more than a high school education may also have different technical education and experience. Thus, schooling and on-the-job training are an enabling factor in profitable innovation which suggests that investments in skills help expand the group of firms in the economy that have the potential to innovate. This finding is corroborated by Abdu and Jibir (2017), D'Este et al. (2014), Dostie (2014, 2018), Sun et al. (2017), van Uden et al. (2014), and van Uden et al. (2016).

The result reveals that an enterprise's propensity to introduce innovation is higher when it spends on R \& D. Involvement in research and development would help the enterprise search new things, to adopt, to develop, and to use them to achieve the enterprise's objectives. As research and development are concerned with searching new mechanisms that solve problems, enterprises also use research and development to 
advance to their predetermined goals. Research and development may help enterprises to use the available internal and external resources. Research and development added to the on-the-job training would enhance the absorption capacity and stock of knowledge of the enterprises that would induce innovation of the enterprises. The findings of Rehman (2016) conducted in India and those of Abdu and Jibir (2017) in Nigeria corroborate this finding. The study support that R \& D has a positive impact on the product and process innovation. Another study also shows that enterprises that received a grant for research and development increase the probability that a firm introduces new goods and services to the world (Jaffe and Le 2015). A study by Yuan et al. (2014) shows that R \& D investment intensity positively determines the firm's innovation though the relationship is weak. However, this study showed that the effects of $\mathrm{R} \& \mathrm{D}$ on process innovation and any product innovation are much weaker.

The top manager's experience in years determines a new method of marketing innovation. A longer time the manager stays in the enterprises enriches the experience of the manager in every aspect of the enterprises. It might also provide an opportunity for the manager to deal with the innovation of the enterprise. The manager of the enterprise knows the areas that need improvement, and probably, it is the top manager that is exactly keen for the accomplishment of the strategic objective of the enterprise. In this case, the longer the stay of the top manager in the enterprise, the more experienced is the manager about the enterprise. It is argued that managers are likely to have better insights into future business opportunities, threats, niche markets, products, technologies, and market development; in this case, top managerial experience is expected to be positively related to innovative activity and its performance. Managerial experience enhances both the propensity to innovate and the innovative firm performance, as measured by the share of sales accounted for by new products (Balsmeier and Czarnitzki 2014). Thus, the experience of the top manager would help peruse marking innovation that helps achieve the objective. However, a study by Yuan et al. (2014) indicated that the top management team's tenure and firm innovation are negatively related.

An enterprise's size determines innovation in all cases except the new market innovation. The size of the firm goes with the capital and human capital. The higher the size of the enterprises, the more they can afford training, $R \& D$, and education and the more the enterprises are innovative. A larger enterprise can amortize fixed costs over a broader base and will, therefore, be more innovative than smaller firms. Moreover, due to their broad base of resources and capabilities, large enterprises are more likely innovative as compared to small ones. The assertion that the size of the enterprise positively affects the innovativeness of the enterprise is also supported by van Uden et al. (2014), van Uden et al. (2016), Leyden et al. (2014), Chowhan (2016), and Mahendra et al. (2015).

Location of the enterprise significantly determines new product innovation. The fact that enterprises that are located in the capital city of the country are more innovative than enterprises located outside the capital city can be explained by the compounding effect of the city and the localization (urbanization) economies of the enterprises. The compounding effect of the city is related to the government emphasis on all sectors in the city including the enterprise development. The localization (urbanization) economies' effect is related to that enterprise densely populated in the city which may easily 
learn from each other either in the formal or informal or in both ways. This may thus help enterprises located in the capital city to be more innovative than others. The assertion here is that in the capital cities' information, the capital (human and physical) easily and freely moves from one enterprise to another. This finding is corroborated by the case of Silicon Valley which is well known for being a learning region and where a successful innovation system has been implemented (Doloreux 2003). Porter and Stern (2001) also argue that location matters for innovation; particularly, most attractive locations enhance the environment for innovation.

\section{Innovation in large-sized enterprises}

For the large-sized enterprise, the MVP regression shows that only the availability of formal training programs for permanent full-time employees and the engagement in formal R \& D activities significantly determine the four types of enterprise innovations. This finding suggests that enterprises that emphasize on the on-the-job training of the employee and research and development are more innovative than others. This finding convinces that enterprise innovation whether it is a new product or a new process or new management or new market innovation, human capital accumulation through training, research, and development is indispensable. In this study, it is also indicated that in the all-sized enterprises, training and $R \& D$ enhance the innovation of the enterprises.

\section{Innovation in medium-sized enterprises}

Regarding medium-sized enterprise innovation, the MVP regression shows that availability of formal training programs for permanent full-time employees and engagement in formal R \& D activities determine new product innovation. Engagement in R \& D activities determine a new method of the production innovation. The new organizational structure innovation is determined by website ownership, the availability of formal training programs for permanent full-time employees, the number of permanent full-time workers, and the engagement in formal R \& D activities. Here, permanent full-time worker increases determines the new organizational structure innovation. The explanation for this is that with an increased number of the full-time permanent workers, diverse ideas and experiences would interact that adds to the enterprise innovativeness. Website ownership and engagement in R \& D determine a new method of marketing innovation. In the medium-sized enterprises, the only variable that affects the four enterprise innovations is an engagement in formal $R \& D$.

\section{Innovation in micro- and small-sized enterprises}

For the micro- and small size, the regression result shows that new product innovation is determined by website ownership, a percentage of full-time permanent workers who completed secondary school, the availability of formal training programs for permanent full-time employees, and engagement in formal R \& D activities. The new method of production innovation is determined by the sex of the top manager, the website ownership, and the availability of formal training programs for permanent full-time employees and engagement in R \& D activities. Here, micro- and small enterprises, which have a female as a top manager, are more innovative in a new method of production 
innovation. Some empirical studies also contend that female representation in top management improves firm performance that focuses on innovation (Dezsö and Ross 2012). In contrast, in hiring more female managers, companies can be more innovative, but having a top female at the top position negatively influences the innovation if the number of female is lower in the top management team (Lyngsie and Foss 2017).

The new organizational structure innovation is determined by website ownership, a percentage of full-time permanent workers who completed secondary school, availability of formal training programs for permanent full-time employees, and engagement in R \& D activities. The new method of marketing innovation is determined by years of experience of a top manager, website ownership, a percentage of full-time permanent workers who completed secondary school, availability of formal training programs for permanent full-time employees, and engagement in R \& D activities. The top manager's experience determines the new method of marketing innovation in micro- and small enterprises. This is explained that as the top manager works more in the sector, he/she will be experienced in dealing with the selling of product and services.

For the micro- and small enterprise, the regression results showed that website ownership, availability of formal training programs for permanent full-time employees, and engagement in R \& D activities affect the four enterprises innovations.

\section{Conclusions}

This study comprehensively examined the main determinants of an enterprise's innovation in Ethiopia using a secondary data collected by World Bank. To achieve the objective, the study MVP model was used. This study categorized the enterprises into four groups, unlike other studies which focus on either enterprise of a specific size or enterprises regardless of size. Our findings show that in all-sized enterprises, website ownership, a percentage of full-time permanent workers whose education is above the secondary school, availability of on-the-job training, and engagement in R \& D activities are factors that affect enterprises' innovations. The MVP regression result indicated that for the large-sized enterprises, only the availability of formal training programs for permanent full-time employees and the engagement in R \& D activities determine the four enterprise innovations. For the medium-sized enterprises, the regression result shows that engagement in $\mathrm{R} \& \mathrm{D}$ fosters the four innovations. In the case of micro- and small enterprises, the variables that affect the four enterprise innovations are website ownership, the availability of formal training programs for permanent full-time employees, and engagement in R \& D activities which encourage four of the innovations for micro- and small enterprises.

The finding of the study has strong theoretical implications. First, the finding that schooling and training and R \& D drive innovativeness in performance of the enterprise goes with several empirical findings. For instance, schooling and training are important sources of innovation (Abdu and Jibir 2017; D'Este et al. 2014; Dostie 2014, 2018; van Uden et al. 2014; van Uden et al. 2016). Further, R and D contributes to the innovation (Abdu and Jibir 2017; Jaffe and Le 2015; Yuan et al. 2014). And this goes back to replicate Becker's (1964) notion that maintaining humans possess human capital (skills, knowledge, ability) that can be improved and can impact how people act and affect the business entity.

Second, the finding that shows website ownership drives an innovation of enterprise replicates the works of Scuotto et al. (2016), Martins (2016), Guo et al. (2016), Del 
Giudice et al. (2016), and Bresciani and Ferraris (2016) which contend that social networking sites, global knowledge, and enterprise embeddedness contribute to the innovation performances of enterprises. And this further goes in line with the phenomenon reflected by Schumpeter (1942) that creative destruction produces product and process innovation and knowledge-intensive entrepreneurship (that can be obtained with the help of information through a website) for entrepreneurs that strive to cope with uncertainty generate changes or creative destructions.

The finding of the study also has strong policy implications. It suggests that development partners, policymakers, and enterprises should emphasize on $R$ \& $D$ activities, regular on-the-job training, education, and development of a website (information access via the Internet). Specifically, the following policy recommendations help an enterprise enhance their innovation performance: first, conducting on-the-job training on a regular basis to upgrade employee's schooling, skill, and efficiency; second, developing and expanding enterprise's website for acquiring reliable information; and third, activating new and strengthening the existing R \& D activities which are salient strategies that can promote enterprises' innovations and achieve their objectives.

Conducting on-the-job training on a regular basis to upgrade employee's skill and efficiency would boost the capacity of the employee of the enterprises. This can be conducted based on the identified areas on which employee needs training. In this case, careful human power planning that considers the needs of the enterprises and employees is vital. Training that can be pursued can be specific to the enterprise innovations or general. Indeed, it should also be conducted in a regular, sustainable, and variety of manner that ensures the sustainability of the enterprise operation.

Website ownership of the enterprises is indispensable to get information worldwide in this globalization era. Here, an enterprise needs to develop their own website for gaining reliable information that boasts their innovation. Only, developing website does not suffice for promotion of the enterprise innovation; the enterprise also needs to subscribe to the international institutions that encourage their betterment.

The $\mathrm{R} \& \mathrm{D}$ activities can be strengthened by allocating a reasonable amount of budget for $\mathrm{R} \& \mathrm{D}$, by encouraging their workers to conduct $\mathrm{R} \& \mathrm{D}$, and by making some linkages with institutions that have ample experience in $\mathrm{R} \& \mathrm{D}$ activities. Concerned bodies may incentivize their worker to conduct R \& D that result in important enterprise innovations that would have a long-lasting impact on the productivity and profitability of the enterprises.

Finally, this study is limited to the Ethiopian enterprises and difficult to generalize to all developing countries. The study also used all enterprises. Therefore, future researchers that emphasize on the enterprises' innovation better consider different countries in the developing countries. Future researchers may also study innovation performances of enterprises based on the sector type, for instance, manufacturing enterprises and trade enterprises.

\section{Methods}

Data source and analytical methods

This study used the 2015 Ethiopia Enterprise Surveys (ES) data collected by the World Bank (World Bank 2016) from June 2015 to February 2016. The ES is a panel data 
which are an ongoing World Bank project in collecting both objective data based on enterprises' experiences and enterprises' perception of the environment in which they operate. The sample for the 2015 Ethiopia's enterprise survey was selected using stratified sampling, following the standard methodology. Three levels of stratification were used in the country: industry, establishment size, and region. Industry stratification was designed in the way that follows: the universe was stratified into four manufacturing industries (food and beverages), textile and garments including leather, non-metallic mineral products, and other manufacturing and three service sectors (transportation, retail) and other services. Size stratification was defined as follows: small (5 to 19 employees), medium (20 to 99 employees), and large (more than 99 employees). Regional stratification for the 2015 Ethiopia ES was done across six geographic regions: Addis Ababa and Dire Dawa City administrations and Amhara, Oromia, SNNPR, and Tigray regional states. For this study, the data were pooled together.

\section{Stating the multivariate probit model}

Behavioral response models with more than two possible outcomes are either multinomial or multivariate. Multinomial models are suitable when respondents can choose only one outcome among the set of mutually exclusive and collectively exhaustive choices. However, in this study, the innovation variables are not mutually exclusive, considering the possibility of the simultaneous involvement of innovation types and the potential correlations between them. Specifically, we examine factors related to different innovations with the following enterprise innovations: new product innovation, new method of production innovation, new organizational structure innovation, and new organizational innovation. The first innovation-dependent variable, new product innovation (h1), takes the value 1 if the enterprise has introduced new or significantly improved products or services during the last 3 years, otherwise 0 . The second innovation-dependent variable, new method of production innovation (h3), takes the value 1 if the enterprise has introduced any new or significantly improved methods of manufacturing products or offering services during the last 3 years, otherwise 0 . The third innovation-dependent variable, new organizational structure innovation (h5), takes the value 1 if the enterprise has introduced any new or significantly improved organizational structures or management practices during the last 3 years, otherwise 0 . The fourth innovation-dependent variable, new marketing method innovation (h6), takes the value 1 if the enterprise has introduced new or significantly improved marketing methods during the last 3 years, otherwise 0 .

We apply the multivariate probit (MVP) to estimate the jointly dependent variables that exploit a system of simultaneous equations. It is a special case of seemingly unrelated regression (SUR) when the dependent variable is of categorical type. In circumstances where cross-equation error terms are correlated and explanatory variables are same across equations, the MVP model can generate more efficient parameter estimates than single-equation estimation approaches.

The description of a regression model is given as: 


$$
Y_{i j}=X_{i j}^{\prime} B_{j}+\varepsilon_{i j}
$$

where $Y_{i j}(j=1, \ldots, m)$ represents the enterprise innovation (in our case, $m=4$ ) taken up by the $i$ th entereprise $(i=1, \ldots, n), X_{i j}$ is a $1 \times k$ vector of observed variables that are expected to correlate with the enterprises innovation, $B j$ is a $k \times 1$ vector of unknown parameters (to be estimated), and $\varepsilon i j$ is the random error term. In this specification, each $Y_{j}$ is a binary variable, and thus, Eq. (1) is a system of $m$ equations ( $m=4$, in this case) to be estimated:

$$
\left\{\begin{array}{l}
Y_{1}^{*}=\alpha_{1}+X B_{1}+\varepsilon_{1} \\
Y_{2}^{*}=\alpha_{2}+X B_{2}+\varepsilon_{2} \\
Y_{3}^{*}=\alpha_{3}+X B_{3}+\varepsilon_{3} \\
Y_{4}^{*}=\alpha_{4}+X B_{4}+\varepsilon_{4}
\end{array}\right.
$$

with $Y_{1}^{*}, Y_{2}^{*}, Y_{3}^{*}, Y_{4}^{*}$ as a set of four latent variables underlying each of the enterprise's innovation such that $Y_{j}=1$ if $Y_{j}^{*}>0 ; 0$ otherwise.

\section{Additional file}

Additional file 1: Supporting Material. (DTA $1925 \mathrm{~kb}$ )

\section{Availability of data and materials}

See additional supporting files (Additional file 1).

\section{Authors' contributions}

All authors have contributed substantially to the development of the manuscript. All authors read and approved the final manuscript.

\section{Competing interests}

The authors declare that they have no competing interests.

\section{Publisher's Note}

Springer Nature remains neutral with regard to jurisdictional claims in published maps and institutional affiliations.

\section{Author details}

'Department of Economics, Haramaya University, Dire Dawa, Ethiopia. ${ }^{2}$ Department of Economics, Jigjiga University, Jigjiga, Ethiopia.

Received: 19 December 2017 Accepted: 31 May 2018

Published online: 27 July 2018

\section{References}

Abderrezzak, B, Wafaa, B, Benabbou, S. (2016). Key determinants of innovation in the Algerian SMEs abstract. Topics in Middle Eastern and African Economies, 18(1), 183-200.

Abdu, M, \& Jibir, A. (2017). Determinants of firms innovation in Nigeria. Kasetsart Journal of Social Sciences, 1-9 https:// doi.org/10.1016/j.kjss.2017.07.006.

Adebowale, BA, Diyamett, B, Lema, R, Oyelaran-Oyeyinka, O. (2014). Special issue: innovation research and economic development in Africa. African Journal of Science, Technology, Innovation and Development, 6(5), v-xi https://doi.org/ 10.1080/20421338.2015.1010774.

African Union Commission (AUC). (2014). Science, technology and innovation strategy for Africa 2024(STISA-2024). AUC, Addis Ababa, Ethiopia

Alsharkas, Z. (2014). Firm size, competition, financing and innovation. International Journal of Management and Economics, 44(1), 51-73 https://doi.org/10.1515/ijme-2015-0009.

Anderson, N, Potočnik, K, Zhou, J. (2014). Innovation and Creativity in Organizations. Journal of Management, 40(5), 1297-1333.

Aralica, Z., Racic, D., \& Radic, D. (2008). Innovation propensity in Croatian enterprises: results of the Community Innovation SurveySouth East European Journal of Economics and Business.

Arrow, K. (1962). The economic implications of learning by doing. American Economic Review, 29(3), 155-173 https://doi. org/10.2307/2295952.

Atkinson, R. D. (2013). Innovation and Productivity: Clearing up the confusion. 
Audretsch, DB, Kuratko, DF, Link, AN. (2016). Dynamic entrepreneurship and technology-based innovation. Journal of Evolutionary Economics, 26(3), 603-620.

Avermaete, T, Viaene, J, Morgan, EJ, Mahon, D. (2004). Determinants of product and process innovation in small food manufacturing. Trends in Food Science \& Technology, 15, 474-483. https://doi.org/10.1016/j.tifs.2004.04.005.

Balsmeier, B, \& Czarnitzki, DW (2014). How important is industry-specific managerial experience for innovative firm performance? ZEW Discussion Paper (pp. 14-011).

Becheikh, N, Landry, R, Amara, N. (2006). Lessons from innovation empirical studies in the manufacturing sector: a systematic review of the literature from 1993-2003. Technovation, 26(May). https://doi.org/10.1016/j.technovation.2005.06.016.

Becker, GS (1964). Human capital: a theoretical and empirical analysis, with special reference to education, (vol. 24). Chicago: The University of Chicago Press.

Beyene, KT, Shi, CS, Wu, WW. (2016). The Impact of Innovation Strategy on Organizational Lerning and Innovation. South African Journal of Industrial Engineering May, 27(May), 125-136.

Bresciani, S, \& Ferraris, A. (2016). Innovation-receiving subsidiaries and dual embeddedness: impact on business performance. Baltic Journal of Management, 11(1), 108-130. https://doi.org/10.1108/BJM-11-2014-0200.

Choi, Y, \& Lim, U. (2017). Contextual Factors Affecting the Innovation Performance of Manufacturing SMEs in Korea: A Structural Equation Modeling Approach. Sustainability, 9(7), 1193.

Chowhan, J. (2016). Unpacking the black box: understanding the relationship between strategy, HRM practices, innovation and organizational performance. Human Resource Management Journal, 26(2), 112-133. https:/doi.org/10.1111/1748-8583.12097.

D'Este, P, Rentocchini, F, Vega-Jurado, J. (2014). The role of human capital in lowering the barriers to engaging in innovation: evidence from the Spanish Innovation Survey. Industry and Innovation, 21(1), 1-19. https://doi.org/10. 1080/13662716.2014.879252.

De Mel, S., Mckenzie, D. \& Woodruff, C. (2009). Innovative firms or innovative owners? Determinants of innovation in micro, small, and medium enterprises, (3962).

Del Giudice, M, Elias, G, Maggioni, V. (2016). Global knowledge intensive enterprises and international technology transfer: emerging perspectives from a quadruple helix environment. The Journal of Technology Transfer. https://doi. org/10.1007/s10961-016-9496-1.

Dezsö, CL, \& Ross, DG. (2012). Does female representation in top management improve firm performance? A panel data investigation. Strategic Management Journal, 33(9), 1072-1089. https://doi.org/10.1002/smj.1955.

Doloreux, D. (2003). Regional innovation systems in the periphery: the case of the Beauce in Québec (Canada). International Journal of Innovation Management, 7(1), 67-94. https://doi.org/10.1142/S1363919603000738.

Dostie, B. (2014). Innovation, productivity, and training. IZA Discussion Papers, 8506.

Dostie, B. (2018). The impact of training on innovation. ILR Review, 71(1), 64-87. https://doi.org/10.1177/0019793917701116.

Dotun, FO. (2015). The key determinants of innovation in small and medium scale enterprises in Southwestern Nigeria, $11(13), 465-479$

Egbetokun, A, Atta-ankomah, R m, Jegede, O. (2016). Firm-level innovation in Africa: overcoming limits and constraints. Innovation and Development, 9318. https://doi.org/10.1080/2157930X.2016.1224619.

El Elj, M, \& El Elj, M. (2012). Innovation in Tunisia: empirical analysis for industrial sectors. Journal of Innovation Economics \& Management, 1. https://doi.org/10.3917/jie.009.0183.

Ethiopian Science and Agency Technology (ESTA). (2006). National Science, Technology and Innovation ( STI ) Policy of Ethiopia. Addis Ababa, Ethiopia. Retrieved from https://www.healthresearchweb.org/files/Ethiopia_National_S,T\&I_ Policy_Draft.2006.pdf.

Gebreeyesus, M (2011). Innovation and microenterprise growth in Ethiopia. In Entrepreneurship, Innovation, and Economic Development. https://doi.org/10.1093/acprof:oso/9780199596515.003.0006.

Goedhuys, M, Janz, N, Mohnen, P. (2014). Knowledge-based productivity in \&quot;low-tech\&quot; industries: evidence from firms in developing countries. Industrial and Corporate Change, 23(1), 1-23 https://doi.org/10.1093/icc/dtt006.

Guo, D, Guo, Y, Jiang, K. (2016). Government-subsidized R \& D and firm innovation: evidence from China. Research Policy, 45(6), 1129-1144 https://doi.org/10.1016/j.respol.2016.03.002.

Hadhri, W., Arvanitis, R., \& M'Henni, H. (2016). Determinants of innovation activities in small and open economies: the Lebanese business sector.

Hashi, I, \& Stojcic, N. (2013). Knowledge spillovers, innovation activities, and competitiveness of industries in EU member and candidate countries. Economic Annals, 58(198), 7-34 https://doi.org/10.2298/EKA1398007H.

Jaffe, AB, \& Le, T (2015). The impact of R\&D on innovation: a study of New Zealand firms (no. 21479). Cambridge.

Johnson, JD, Meyer, ME, Berkowitz, JM, Ethington, CT, Miller, VD. (1997). Testing two contrasting structural models of innovativeness in a contractual network. Human Communication Research, 24(2), 320-348 https://doi.org/10.1111/j. 1468-2958.1997.tb00417.x.

Koouba, K, M'henni, H, Gabsi, F. (2010). Innovation determinants in emerging economies: an empirical study based on an innovation survey data in Tunisia. International Journal of Technological Learning, Innovation and Development, 3(3), 205-225.

Leyden, DP, Link, AN, Siegel, DS. (2014). A theoretical analysis of the role of social networks in entrepreneurship. Research Policy, 43(7), 1157-1163. https://doi.org/10.1016/j.respol.2014.04.010.

Lyngsie, J, \& Foss, NJ. (2017). The more, the merrier? Women in top-management teams and entrepreneurship in established firms. Strategic Management Journal, 38(3), 487-505. https://doi.org/10.1002/smj.

Mahendra, E, Zuhdi, U, Muyanto, R. (2015). Determinants of firm innovation in Indonesia: the role of institutions and access to finance. Economics and Finance in Indonesia, 61(3), 149-179.

Martínez-ros, E, \& Labeaga, JM. (2002). The relationship between firm size and innovation activity: a double decision approach. Economics of Innovation and New Technology, 11(1), 37-41.

Martins, I. (2016). Network usage, entrepreneurial orientation and their effectiveness on SMEs growth. Journal of Entrepreneurship, 25(1), 18-41. https://doi.org/10.1177/0971355715616230.

Moohammad, AY, Aini, YN, Kamal, EM. (2014). Influences of firm size, age and sector on innovation behaviour of construction consultancy services organizations in developing countries. Business Management Dynamics, 4(4), 1-9. 
Mowery, D, \& Rosenberg, N. (1989). New developments in US technology policy: implications for competitiveness and international trade policy. California Management Review, 32(1), 107-124. https://doi.org/10.2307/41166737.

Nam, TH, Tuan, NP, Van Minh, N. (2017). Critical Successful Factors for Innovation in Vietnamese Firms. Journal of Industrial Engineering and Management, 10(3), 522-544. https://doi.org/10.3926/jiem.2020.

NEPAD Planning and Coordinating Agency (NPCA) (2014). African innovation outlook II. Pretoria: NPCA.

Organizations for Economic Co-operation (OECD). (2010). The measurement of scientific and technological activities: proposed guidelines for collecting and interpreting technological innovation data.

Plehn-Dujowich, J. (2009). Economics of innovation and new technology. Economics of Innovation and New Technology., 8(3), 37-41.

Porter, ME, \& Stern, S. (2001). Innovation: location matters. MIT Sloan Management Review, 42 (4 Summer 2001), 28-36 https://doi.org/10.1016/j.neuron.2009.08.001.

Raymond, L, \& St-Pierre, J. (2010). R\&D as a determinant of innovation in manufacturing SMEs: an attempt at empirical clarification. Technovation, 30(1), 48-56. https://doi.org/10.1016/j.technovation.2009.05.005.

Rehman, NU. (2016). Does internal \& external research and developement affect innovation of small and medium-sized enterprises? Evidence from India and Pakistan. ADBI Working Paper, 1-25.

Romijn, H, \& Albaladejo, M. (2002). Determinants of innovation capability in small electronics and software firms in Southeast England. Research Policy, 31(7), 1053-1067. https://doi.org/10.1016/S0048-7333(01)00176-7.

Santamaría, L, Nieto, MJ, Barge-Gil, A. (2009). Beyond formal R\&D: taking advantage of other sources of innovation in low- and medium-technology industries. Research Policy, 38(3), 507-517. https://doi.org/10.1016/j.respol.2008.10.004

Schumpeter, JA. (1942). Capitalism and the process of creative destruction. Monopoly Power and Economic Performance, 19-38. https://doi.org/10.1017/CBO9781107415324.004.

Scuotto, V, Del Giudice, M, Carayannis, EG. (2016). The effect of social networking sites and absorptive capacity on SMES' innovation performance. The Journal of Technology Transfer. https://doi.org/10.1007/s10961-016-9517-0.

Stojčić, N, \& Hashi, I. (2014). Firm productivity and type of innovation: evidence from the Community Innovation Survey 6. Croatian Economic Survey, 16(2), 121-146 https://doi.org/10.15179/ces.16.2.5.

Sun, X., Li, H., \& Ghosal, V. (2017). Firm-level human capital and innovation: evidence from China. In CESifo Area Conference on Applied Microeconomics (pp. 1-36). Munich, Germany.

Teece, DJ. (1986a). Profiting from technological innovation. Research Policy. https:/doi.org/10.1016/0048-7333(93)90063-N

Teece, DJ. (1986b). Profiting from technological innovation: implications for integration, collaboration, licensing and public policy. Research Policy, 15(6), 285-305. https://doi.org/10.1016/0048-7333(86)90027-2.

van Uden, A., Knoben, J., \& Vermeulen, P. (2016). Human capital and innovation in sub-Saharan countries: a firm-level study. Innovation: Management, Policy and Practice, (October), 1-22. https://doi.org/10.1080/14479338.2016.1237303

van Uden, A., Knoben, J., \& Vermeulen, P. (2014). Human capital and innovation in developing countries: a firm level sturdy. Nijmegen.

World Bank. (2016). Ethiopia - Enterprise Survey 2015. Retrieved from http://microdata.worldbank.org/index.php/ catalog/2577/export

Yuan, X., Guo, Z., \& Fang, E. (Er). (2014). An examination of how and when the top management team matters for firm innovativeness: the effects of TMT functional backgrounds, Innovation: Management, Policy and Practice, 16(3), 323-342. https://doi.org/10.1080/14479338.2014.11081991

Zakic, N, Jovanovic, A, Stamatovic, M. (2008). External and internal factors affecting the product and business process innovation. Economics and Organization, 5(1), 17-29.

Zemplinerová, A, \& Hromádková, E. (2012). Determinants of firm's innovation. Prague Economic Papers, (4), 487-503 https://doi.org/10.18267/j.pep.436.

\section{Submit your manuscript to a SpringerOpen ${ }^{\circ}$ journal and benefit from:}

- Convenient online submission

- Rigorous peer review

Open access: articles freely available online

High visibility within the field

- Retaining the copyright to your article

Submit your next manuscript at $>$ springeropen.com 